\title{
Determination of the soil water repellency of the Mediterranean climate by the use of the mini disk infiltrometer. Case of the micro basin of Tifiles, Tenes, Algeria.
}

\author{
Abderrahman Kessaissia $^{\text {* (D) }}$, Mohamed Mazour ${ }^{2}$ \\ 'University of Hassiba Benbouali, Chlef, Algeria \\ ${ }^{2}$ Ain Temouchent University Center, Ain Temouchent, Algeria \\ *Corresponding author, e-mail: akessaissiadz@yahoo.fr
}

\begin{abstract}
The soil repellency is one of some soil propriety that can be use to indicate the quality of the soil and give a number of information for the soil conservation and the water management. This study show an example of the determination of this parameter in three sites (forest site, after fire forest site and mixed site) by the use of the mini disk infiltrometer test (MDIT) in the small watershed of wadi Tifiles situated in the North West of Algeria that is characterized by a Mediterranean climate. The result show that the water repellency affect namely the after fire forest site which can be equal to $100 \%$ of the measured sample flowed by the mixed soil by $93 \%$ and the forest site by $80 \%$.
\end{abstract}

Keywords: soil, water repellency, infiltration test

\section{Introduction}

The soil water repellency is an indicator used in the assessment of land degradation. It is defined as the inability to get wet or water to seep into the soil (Doerr et al., 2000), it is an unstable phenomenon, it is more pronounced when the soil is drier, it can happen naturally or after forest fires (Robichaud et al., 2000) and it is generally indicated as the reduction of the amount of water infiltration in the soil (Telman et al., 2000; Krolow ef al., 2019).

The effect of the soil water repellency on erosion and infiltration is very remarkable. On erosion it can be showed by its potential for increasing overland flow (Meeuwig 1970) and by altering the erodibility of the soil by either wind or water action (Shakesby et al., 2000) and on infiltration it can resist or retard surface water infiltration (Brandt, 1969). The reduction of the water infiltration can cause the reduction of the amount of water in the soil necessary for the growth and the development of plants (Hallet, 2008).

The soil water repellency can be determined by three main methods: i) water drop penetration time test (WDPT) (De Bano, 1998); and ii) the molarity ethanol drop test (MEDT), (King, 1981) and MDIT.
The present study shows the determination of soil water repellency by MDIT in a forest watershed that is dominated by three types of land use and located on slopes: a forest site, a post-fire forest site and a pasture - agricultural site (mixed site). The forest area is often exposed to the fire and the mixed sites are generally worked without conservation measure. Therefore, during the rainfall event, areas located at the bottom of the watershed records of remarkable floods and lead to a serious damage, like the destruction of the infrastructure (road, houses).

Thus, the main objective of this study is: to characterize the soil water repellency of the main sites of the study area and then to identify sites that will responsible to cause run off and flooding registered at the downstream area of the watershed.

\section{Material and Methods}

Study situation

This work is carried out in the micro watershed of Tifiles, located in the northwestern part of the Algeria between $1^{\circ} 20^{\prime}$ East longitude and $36^{\circ} 32^{\prime}$ latitude North (Figure 1). 


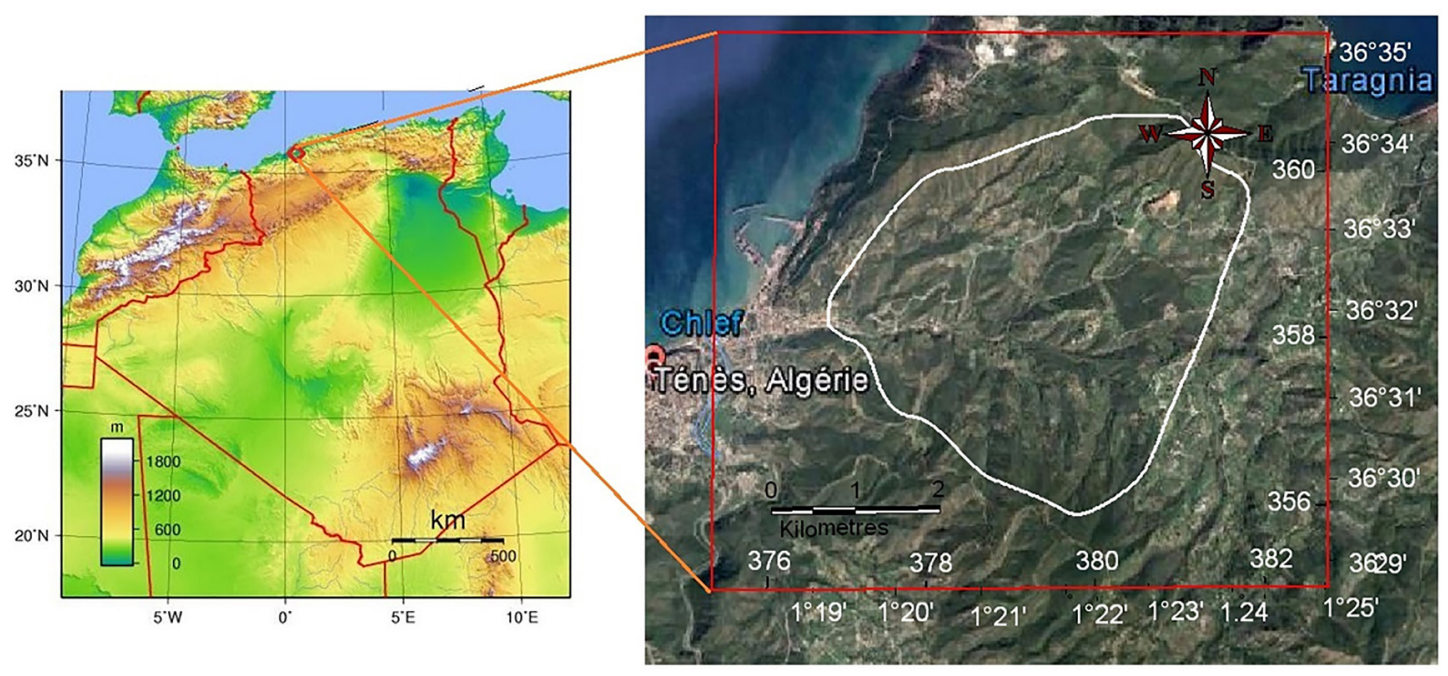

Figure 1. Situation of the study area.

The physical environment of the area is characterized by the slopes ranging from 10 to $40 \%$, a Mediterranean climate characterized by of annual rainfall and annual temperature successively equal to $448 \mathrm{~mm}$ and to $19^{\circ} \mathrm{C}$ (Table 1). The lithology is characterized by a diversity of the superficial formations with predominance of Marly soils that are characterized by a high sensitivity to water erosion. The soil granulometric analysis of the three sites shows that the soil is dominated by a silt-clay texture (Table 2). The occupation of the soil is dominated by conifer forestry species including Aleppo Pine and cedar of Barbary that occupying the largest area and the rest of the area consists of scrub, xerophilic herbaceous vegetation.

\section{Characteristics of the sites}

This study is conducted in three sites specified by the occupancy and the land use. The characteristics localization sites are listed in Table 3.

Table 1. Monthly run fall and monthly temperature registered in study area (1982-2012).

\begin{tabular}{cccccccccccccc}
\hline Month & 09 & 10 & 11 & 12 & 01 & 02 & 03 & 04 & 05 & 06 & 07 & 08 & Year \\
\hline $\mathrm{P}(\mathrm{mm})$ & 18.8 & 39.6 & 83.3 & 65.6 & 52.8 & 49.2 & 47.2 & 38.2 & 38.4 & 6.8 & 2.2 & 6.1 & 448.3 \\
\hline $\mathrm{T} \mathrm{en}^{\circ} \mathrm{C}$ & 25.1 & 19.2 & 15.1 & 11.9 & 12.1 & 12.8 & 14.0 & 15.2 & 18.9 & 22.3 & 25.5 & 29.9 & 18.5 \\
\hline
\end{tabular}

Table 2. Physical and chemical characteristics in percentage (\%).

\begin{tabular}{lccc}
\hline Parameters & Forest site & After fire forest site & Mixed site \\
\hline Clay & 21.59 & 21.59 & 22.25 \\
\hline Fine silt & 15.58 & 15.58 & 18.14 \\
\hline Thick silt & 22.52 & 22.52 & 16.66 \\
\hline Fine sand & 24.77 & 24.77 & 28.99 \\
\hline Thick sand & 14.83 & 14.83 & 12.99 \\
\hline Organic matter & 9.97 & 7.5 & 3.63 \\
\hline
\end{tabular}

Table 3. Localization of the study sites.

\begin{tabular}{lccccc}
\hline Sites & Latitude & Longitude & Altitude $(\mathrm{m})$ & Mean slope (\%) & Exposition \\
\hline Forest site & $36^{\circ} 30^{\prime} 90.9^{\prime \prime}$ & $1^{\circ} 19^{\prime} 46^{\prime \prime}$ & 80 & 11 & North west \\
\hline After forest site & $36^{\circ} 30^{\prime} 35^{\prime \prime}$ & $1^{\circ} 20^{\prime} 00^{\prime \prime}$ & 180 & 15 & North west \\
\hline Mixed site & $36^{\circ} 30^{\prime} 51^{\prime \prime}$ & $1^{\circ} 20^{\prime} 14^{\prime \prime}$ & 160 & 14 & North west \\
\hline
\end{tabular}

\section{Description the MDI}

The $\mathrm{MDI}$ is consisting to investigate the hydrodynamic functioning of the soil that have $0.12 \mathrm{~mm}$ pore diameter.

Characteristics

Total length: $32.7 \mathrm{~cm}$

Diameter of tube: $3.1 \mathrm{~cm}$
Sintered stainless steel disc: $4.5 \mathrm{~cm}$ diameter and $3 \mathrm{~mm}$ thick

Length of suction regulation tube: $10.2 \mathrm{~cm}$

Succion range: 0.5 à $7.0 \mathrm{~cm}$ of succion

Length of water reservoir: $21.2 \mathrm{~cm}$

Length of Marriott tube: $28.0 \mathrm{~cm}$

Volume of water required to operate: $135.0 \mathrm{ml}$ 
The method is based on the application of the MDIT along three parallel transects of 100 meters length and distant by 10 meters. The determination of soil water repellency is inspired from the method used by Robichaud et al. (2000). It is consisting to measure the amount of water that penetrates into the soil per minute. The test is applied in three repeated tests for each measure point. From $0,10,30,60$ and 100 meters along each transect at the level of $1 \mathrm{~cm}$ and $3 \mathrm{~cm}$ of depth.

The application of these measures at the level of $1 \mathrm{~cm}$ and $3 \mathrm{~cm}$ deep is considered to the previous studies that have shown that the water repellency is limited especially in the first centimeters of the soil surface (Robichaud et al., 2000).

\section{Results and Discussion}

The results of the water repellency according to the American classification (Robichaud, 2008) is indicated in the following Tables $(4,5,6,7,8$ and 9) show that the three sites are characterized by a strong water repellency ranging from $80 \%$ to $20 \%$ in the forest site, from $93 \%$ to $7 \%$ in the mixed site and $100 \%$ in the after fire forest site.

Table 4. Soil water repellency in the forest site at $1 \mathrm{~cm}$ depth.

\begin{tabular}{|c|c|c|c|c|c|c|c|c|}
\hline \multirow{2}{*}{ Transects } & \multirow{2}{*}{ Measure position } & \multicolumn{4}{|c|}{ MDI test (ml min-1.) } & \multicolumn{3}{|c|}{ Water repellency class } \\
\hline & & Test 1 & Test 2 & Test 3 & Average & Strong $<3$ & Low 3-8 & Without $\geq 8$ \\
\hline \multirow{5}{*}{ Transect 1} & 0 & 0.5 & 1 & 2 & 1.75 & + & & \\
\hline & 10 & 0.1 & 2 & 1 & 1.55 & + & & \\
\hline & 30 & 1.5 & 1.5 & 0.5 & 1.75 & + & & \\
\hline & 60 & 0.5 & 2 & 1.5 & 2 & + & & \\
\hline & 100 & 3.5 & 0.5 & 1.5 & 2.75 & + & & \\
\hline \multirow{5}{*}{ Transect 2} & 0 & 0.5 & 0.8 & 2.5 & 1.27 & + & & \\
\hline & 10 & 3 & 2.2 & 4 & 3.07 & & + & \\
\hline & 30 & 1 & 1.5 & 2 & 1.5 & + & & \\
\hline & 60 & 1.5 & 1.5 & 0.8 & 1.27 & + & & \\
\hline & 100 & 1.5 & 0.8 & 1.2 & 1.17 & + & & \\
\hline \multirow{5}{*}{ Transect 3} & 0 & 3.1 & 7 & 3.5 & 4.54 & & + & \\
\hline & 10 & 0.9 & 2 & 1.2 & 1.37 & + & & \\
\hline & 30 & 4 & 3 & 3 & 3.33 & & + & \\
\hline & 60 & 1 & 1 & 0.5 & 0.83 & + & & \\
\hline & 100 & 2 & 1 & 1 & 1.3 & + & & \\
\hline \multicolumn{6}{|c|}{ Water repellency samples number } & 12 & 3 & 0 \\
\hline \multicolumn{6}{|c|}{ Percentage } & 80 & 20 & 0 \\
\hline
\end{tabular}

Table 5. Soil water repellency in the forest site at $3.0 \mathrm{~cm}$ depth.

\begin{tabular}{|c|c|c|c|c|c|c|c|c|}
\hline \multirow{2}{*}{ Transects } & \multirow{2}{*}{ Measure position } & \multicolumn{4}{|c|}{ MDI test (ml min-1.) } & \multicolumn{3}{|c|}{ Water repellency class } \\
\hline & & Test 1 & Test 2 & Test 3 & Average & Strong $<3$ & Low 3-8 & Without $\geq 8$ \\
\hline \multirow{5}{*}{ Transect 1} & 0 & 2 & 1 & 0.1 & 1.03 & + & & \\
\hline & 10 & 2 & 1 & 0.2 & 1.07 & + & & \\
\hline & 30 & 1 & 2 & 1.5 & 1.5 & + & & \\
\hline & 60 & 0.5 & 1 & 1.5 & 1 & + & & \\
\hline & 100 & 1 & 2 & 1 & 1.3 & + & & \\
\hline \multirow{5}{*}{ Transect 2} & 0 & 4 & 1.5 & 1.5 & 2.33 & + & & \\
\hline & 10 & 1 & 0.7 & 1 & 0.9 & + & & \\
\hline & 30 & 1.5 & 1.5 & 1.5 & 1.5 & + & & \\
\hline & 60 & 1 & 3 & 1.5 & 1.83 & + & & \\
\hline & 100 & 0.5 & 1 & 1.5 & 1 & + & & \\
\hline \multirow{5}{*}{ Transect 3} & 0 & 1 & 2 & 1 & 1.33 & + & & \\
\hline & 10 & 3 & 2 & 3.5 & 2.83 & + & & \\
\hline & 30 & 3 & 2.5 & 1.5 & 2.33 & + & & \\
\hline & 60 & 4 & 3.5 & 2 & 3.17 & & + & \\
\hline & 100 & 3 & 1.5 & 1 & 1.83 & + & & \\
\hline \multicolumn{6}{|c|}{ Water repellency samples number } & 14 & 1 & 0 \\
\hline \multicolumn{6}{|c|}{ Percentage } & 93 & 7 & 0 \\
\hline
\end{tabular}


Table 6. Soil water repellency at $1 \mathrm{~cm}$ deep in the mixed site.

\begin{tabular}{|c|c|c|c|c|c|c|c|c|}
\hline \multirow{2}{*}{ Transects } & \multirow{2}{*}{ Measure position } & \multicolumn{4}{|c|}{ MDI test (ml min-1.) } & \multicolumn{3}{|c|}{ Water repellency class } \\
\hline & & Test 1 & Test 2 & Test 3 & Average & Strong $<3$ & Low 3-8 & Without $\geq 8$ \\
\hline \multirow{5}{*}{ Transect 1} & 0 & 2 & 3.5 & 1.5 & 2.33 & + & & \\
\hline & 10 & 3.8 & 0.5 & 1 & 1.77 & + & & \\
\hline & 30 & 3 & 2 & 3 & 2.67 & + & & \\
\hline & 60 & 1 & 1.5 & 0.3 & 0.93 & + & & \\
\hline & 100 & 1 & 1 & 1.5 & 1.17 & + & & \\
\hline \multirow{5}{*}{ Transect 2} & 0 & 0.2 & 1 & 0.5 & 1.27 & + & & \\
\hline & 10 & 0.2 & 0.5 & 1 & 3.07 & & + & \\
\hline & 30 & 1 & 1 & 1 & 1.5 & + & & \\
\hline & 60 & 1.2 & 1 & 0.5 & 1.27 & + & & \\
\hline & 100 & 0.2 & 0.3 & 1 & 1.17 & + & & \\
\hline \multirow{5}{*}{ Transect 3} & 0 & 1 & 0.5 & 0.3 & 0.6 & + & & \\
\hline & 10 & 1 & 1 & 0.3 & 0.77 & + & & \\
\hline & 30 & 2 & 1 & 1 & 1.33 & + & & \\
\hline & 60 & 0.5 & 1 & 3.5 & 1.67 & + & & \\
\hline & 100 & 1.2 & 1.5 & 1.5 & 1.4 & + & & \\
\hline \multicolumn{6}{|c|}{ Water repellency samples number } & 14 & 1 & \\
\hline & & entage & & & & 93 & 7 & \\
\hline
\end{tabular}

Table 7. Soil water repellency at $3 \mathrm{~cm}$ deep in the mixed site.

\begin{tabular}{|c|c|c|c|c|c|c|c|c|}
\hline \multirow{2}{*}{ Transects } & \multirow{2}{*}{ Measure position } & \multicolumn{4}{|c|}{ MDI test (ml min-1.) } & \multicolumn{3}{|c|}{ Water repellency class } \\
\hline & & Test 1 & Test 2 & Test 3 & Test 1 & Strong $<3$ & Low 3-8 & Without $\geq 8$ \\
\hline \multirow{5}{*}{ Transect 1} & 0 & 2 & 1 & 2.5 & 1.83 & + & & \\
\hline & 10 & 0.2 & 0.6 & 0.7 & 0.5 & + & & \\
\hline & 30 & 1.5 & 1 & 1 & 1.17 & + & & \\
\hline & 60 & 1 & 1 & 0.5 & 0.83 & + & & \\
\hline & 100 & 1.5 & 1 & 0.5 & 1 & + & & \\
\hline \multirow{5}{*}{ Transect 2} & 0 & 0.3 & 0.4 & 0.3 & 0.33 & + & & \\
\hline & 10 & 1 & 0.2 & 0.5 & 0.57 & + & & \\
\hline & 30 & 3 & 3 & 3 & 3 & + & & \\
\hline & 60 & 1 & 3 & 3 & 2.33 & + & & \\
\hline & 100 & 0.1 & 2.4 & 1.2 & 1.23 & + & & \\
\hline \multirow{5}{*}{ Transect 3} & 0 & 0.5 & 1 & 0.5 & 0.67 & + & & \\
\hline & 10 & 2 & 0.5 & 1.5 & 1.33 & + & & \\
\hline & 30 & 2 & 2 & 1 & 1.67 & + & & \\
\hline & 60 & 1 & 0.2 & 0.8 & 0.67 & + & & \\
\hline & 100 & 0.1 & 0.4 & 1 & 0.5 & + & & \\
\hline \multicolumn{6}{|c|}{ Water repellency samples number } & 15 & 0 & 0 \\
\hline \multicolumn{6}{|c|}{ Percentage } & 100 & 0 & 0 \\
\hline
\end{tabular}

Table 8. Soil water repellency at $1 \mathrm{~cm}$ deep in the after fire forest site.

\begin{tabular}{|c|c|c|c|c|c|c|c|c|}
\hline \multirow{2}{*}{ Transects } & \multirow{2}{*}{$\begin{array}{l}\text { Measure } \\
\text { position }\end{array}$} & \multicolumn{4}{|c|}{ MDI test (ml min-1.) } & \multicolumn{3}{|c|}{ Water repellency class } \\
\hline & & Test 1 & Test 2 & Test 3 & Average & Strong $<3$ & Low 3-8 & Without $\geq 8$ \\
\hline \multirow{5}{*}{ Transect 1} & 0 & 1 & 2.2 & 0.8 & 1.33 & + & & \\
\hline & 10 & 2.5 & 4 & 1 & 2.5 & + & & \\
\hline & 30 & 1 & 0.8 & 1.3 & 1.03 & + & & \\
\hline & 60 & 0.3 & 0.5 & 0.5 & 0.43 & + & & \\
\hline & 100 & 0.2 & 0.3 & 0.2 & 0.23 & + & & \\
\hline \multirow{5}{*}{ Transect 2} & 0 & 0.2 & 1 & 0.5 & 0.57 & + & & \\
\hline & 10 & 0.2 & 0.5 & 1 & 0.56 & + & & \\
\hline & 30 & 1 & 1 & 1 & 1 & + & & \\
\hline & 60 & 1.2 & 1 & 0.5 & 0.9 & + & & \\
\hline & 100 & 0.2 & 0.3 & 1 & 0.5 & + & & \\
\hline \multirow{5}{*}{ Transect 3} & 0 & 0.8 & 1.5 & 0.5 & 0.93 & + & & \\
\hline & 10 & 0.2 & 1.8 & 0.2 & 0.73 & + & & \\
\hline & 30 & 0.5 & 0.5 & 0.5 & 0.5 & + & & \\
\hline & 60 & 0.5 & 0.2 & 0.3 & 0.33 & + & & \\
\hline & 100 & 0.5 & 1.5 & 1 & 1 & + & & \\
\hline \multicolumn{6}{|c|}{ Water repellency samples number } & 15 & 0 & 0 \\
\hline \multicolumn{6}{|c|}{ Percentage } & 100 & 0 & 0 \\
\hline
\end{tabular}


Table 9. Soil water repellency at $3 \mathrm{~cm}$ deep in the after fire forest site

\begin{tabular}{|c|c|c|c|c|c|c|c|c|}
\hline \multirow{2}{*}{ Transects } & \multirow{2}{*}{ Measure position } & \multicolumn{4}{|c|}{ MDI test (ml min-1.) } & \multicolumn{3}{|c|}{ Water repellency class } \\
\hline & & Test 1 & Test 2 & Test 3 & Average & Strong $<3$ & Low 3-8 & Without $\geq 8$ \\
\hline \multirow{5}{*}{ Transect 1} & 0 & 0.5 & 0.2 & 1.2 & 0.63 & + & & \\
\hline & 10 & 1 & 0.5 & 1 & 0.83 & + & & \\
\hline & 30 & 0.5 & 0.7 & 1 & 0.73 & + & & \\
\hline & 60 & 0.5 & 0.5 & 0.5 & 0.5 & + & & \\
\hline & 100 & 0 & 0.2 & 0.7 & 0.3 & + & & \\
\hline \multirow{5}{*}{ Transect 2} & 0 & 0.3 & 0.4 & 0.3 & 0.33 & + & & \\
\hline & 10 & 1 & 0.2 & 0.2 & 0.47 & + & & \\
\hline & 30 & 3 & 3 & 3 & 3 & + & & \\
\hline & 60 & 1 & 2 & 1 & 1.33 & + & & \\
\hline & 100 & 0.1 & 1.6 & 1.2 & 0.97 & + & & \\
\hline \multirow{5}{*}{ Transect 3} & 0 & 1.5 & 1.5 & 0.2 & 1.07 & + & & \\
\hline & 10 & 0.5 & 0.2 & 0.1 & 0.27 & + & & \\
\hline & 30 & 0.1 & 0.1 & 0.1 & 0.1 & + & & \\
\hline & 60 & 0.5 & 0.2 & 0.1 & 0.27 & + & & \\
\hline & 100 & 0.5 & 0.5 & 1 & 0.67 & + & & \\
\hline \multicolumn{6}{|c|}{ Water repellency samples number } & 15 & 0 & 0 \\
\hline \multicolumn{6}{|c|}{ Percentage } & 100 & 0 & 0 \\
\hline
\end{tabular}

The results indicated in the previous tables soil water repellency show that the post fire site is characterized by the high water repellency, followed successively by the mixed site and the forest site. This characterization could be the consequence of hydrophobic layers result of the organic matter combustion. The repetition of the fires could increase the formation of hydrophobic layers which can stay for a length period and conduct these sites to be more hydrophobic and become the suitable areas for the formation of the runoff especially during heavy run fall. For this reason, the areas located in the downstream of this study micro basin record remarkable floods during significant rain fall after the burned period. On the other hand, the reduction of soil water repellency in the forest site could be explained by the role of the different parts of trees from aerial parts (branches, leaves) in the dissipation of the raindrops energy by preventing their direct fall on the soil surface and by the root system that allows water to percolate which contribute in reducing the consequence hydrophobic areas. In fact, this observation converges with the work of Boelhouwers

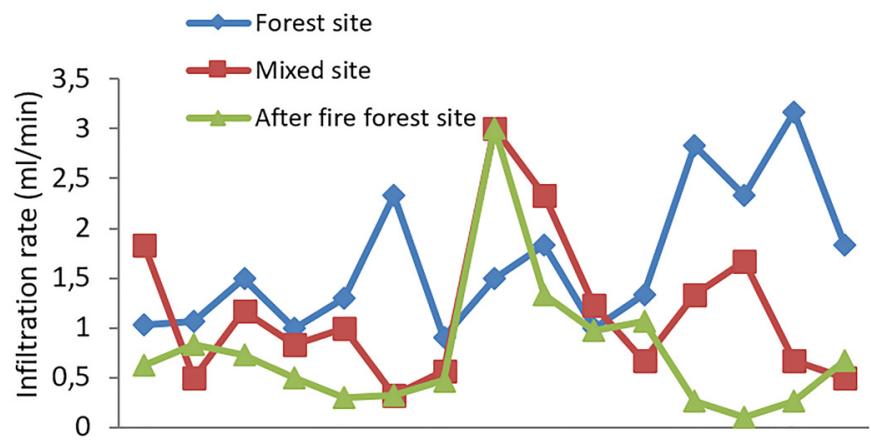

$\begin{array}{lllllllllllllll}1 & 2 & 3 & 4 & 5 & 6 & 7 & 8 & 9 & 10 & 11 & 12 & 13 & 14 & 15\end{array}$

Figure 2. Average infiltration rate at $1 \mathrm{~cm}$ depth from the surface soil. et al. (1996) who have indicated that the fire zones are the more areas favorable to the formation of runoff and the hydrophobic area.

Comparison between the infiltrate rate and the water repellency

The observation of the average values of the infiltration rate Figures 2 and 3 shows that the values of the water infiltration rate are so important in the forest site compared to the after fire forest site and the mixed site. This behavior could indicate that the post-fire forest site soils (characterized by the strong water repellency) are most affected by the reduction of the infiltration, particularly at the level of 1 centimeter depth. This behavior could also indicate that surfaces of the forest sites soils affected by the burned are more exposed to the formation of impermeable layers, particularly just after fire period, or those exposed to repeated fires. This observation is in agreement with the results found in the past studies on the soil infiltration in after fire forest site (Campbell et al., 1977).

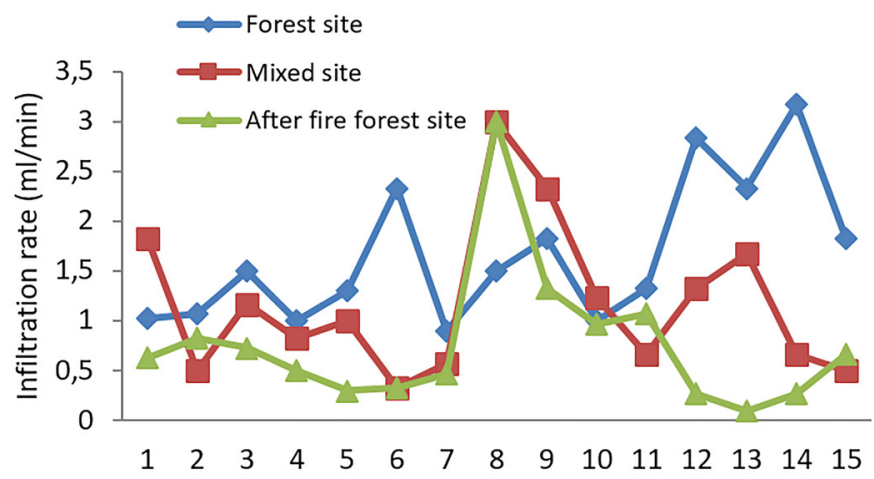

Figure 3. Average infiltration rate at $3 \mathrm{~cm}$ depth from the surface soil. 
Water infiltration rate variation

The infiltration rate $\left(\mathrm{ml} \mathrm{min}^{-1}\right.$.) shows a remarquable

variation namely in the post-fire forest site at $1 \mathrm{~cm}$ and 3 $\mathrm{cm}$ depth as is indicated in the following Tables 10, 11 and 12 .

Table 10. The coefficient of variation of the infiltration rate in the forest site.

\begin{tabular}{lcccccc}
\hline \multicolumn{1}{c}{ Depth } & \multicolumn{1}{c}{$1 \mathrm{~cm}$} & \multicolumn{3}{c}{$3 \mathrm{~cm}$} \\
\hline Transects & Transect 1 & Transect 2 & Transect 3 & Transect 1 & Transect 2 & Transect 3 \\
\hline Measure number & 15 & 15 & 15 & 15 & 15 & 15 \\
\hline Average & 1.31 & 1.65 & 2.28 & 1.19 & 1.51 & 2.3 \\
\hline Standard deviation & 0.84 & 0.92 & 1.66 & 0.61 & 0.86 & 0.92 \\
\hline Coefficient of variation & 0.64 & 0.55 & 0.73 & 0.51 & 0.57 & 0.4 \\
\hline
\end{tabular}

Table 11. The coefficient of variation of the infiltration rate in the mixed site.

\begin{tabular}{lcccccc}
\hline Depth & \multicolumn{1}{c}{$1 \mathrm{~cm}$} & \multicolumn{2}{c}{$3 \mathrm{~cm}$} \\
\hline Transects & Transect 1 & Transect 2 & Transect 3 & Transect 1 & Transect 2 & Transect 3 \\
\hline Measure number & 15 & 15 & 15 & 15 & 15 & 15 \\
\hline Average & 1.77 & 0.71 & 1.15 & 1.06 & 1.49 & 0.96 \\
\hline Standard deviation & 1.05 & 0.35 & 0.77 & 0.58 & 1.19 & 0.62 \\
\hline Coefficient of variation & 0.59 & 0.49 & 0.67 & 0.54 & 0.80 & 0.54 \\
\hline
\end{tabular}

Table 12. The coefficient of variation of the infiltration rate in the after fire forest site.

\begin{tabular}{lcccccc}
\hline Depth & \multicolumn{1}{c}{$1 \mathrm{~cm}$} & & $3 \mathrm{~cm}$ \\
\hline Transects & Transect 1 & Transect 2 & Transect 3 & Transect 1 & Transect 2 & Transect 3 \\
\hline Measure number & 15 & 15 & 15 & 15 & 15 & 15 \\
\hline Average & 1.11 & 0.77 & 0.7 & 0.6 & 1.22 & 0.47 \\
\hline Standard deviation & 1.01 & 0.48 & 0.5 & 0.33 & 1.03 & 0.46 \\
\hline Coefficient of variation & 0.91 & 0.62 & 0.71 & 0.55 & 0.84 & 0.98 \\
\hline
\end{tabular}

For the depth of $1 \mathrm{~cm}$, the coefficient of variation $\mathrm{CV}$ is equal to 0.93 and 0.62 in the post-fire site, 0.73 and 0.55 in the forest site and 0.67 and 0.49 in the mixed site. Similarly at the $3 \mathrm{~cm}$ depth level the $\mathrm{CV}$ varies from 0.98 to 0.55 in the post-fire forest site, 0.80 to 0.54 in the mixed site and 0.51 to 0.40 in the forest site. In general the infiltration rate is more heterogeneous especially at the level of 1 $\mathrm{cm}$ depth.

Variation of the infiltration rate and the soil water repellency

The comparison of the variation of the infiltration rate and the classes of water repellency shows that the variation of infiltration increases with the increase of water repellency. This behavior could indicate that the appearance of the hydrophobic layer can cause an irregularity of the infiltration of water in the soil. On the other hand, the infiltration is low when the soil has a low ground cover and strong water repellency (case of the post fire site and the mixed site). This observation is in accord with that of (Doerr et al., 1998) who they indicated that the variability in water repellency is low in well planted surfaces with an important litter and a good root system.

\section{Conclusions}

The use of the MDIT has permitted the characterization of the soil water repellency in three different sites; forest site, mixed site and after fire forest site. The results show that the water repellency is highest in the after fire forest site namely when it is affected by the repetitive fire which interdict the regeneration of the vegetation. It also show that the water repellency can affect the cumulative infiltration rate and the variability of the infiltration which can disrupt the penetration of water in the soil and can be one of the causes of the runoff apparition at the up areas and flooding at the down areas of the watersheds.

\section{References}

Boelhouwers, J.C., De Graaf, P.J., Samsodien, M.A. 1996. The influence of wildfire on soil properties and hydrological response at Devil's Peak, Cape Town, South Africa. Zeitschrift fur Geomorphologie 107: 1-10.

Brandt, G.H. 1969. Water movement in hydrophobic soils. In: Symposium on Water Repellent Soils. Abstracts... University of California, Riverside, USA. p. 91-115.

Campbell, R.E., Baker, M.B., Jr., Ffliott, P.F., Larson, F.R., Avery, C.C. 1977. Wildfire effects on a ponderosa pine ecosystem: an Arizona case study. Forest Service Research Paper RM-191, Fort Collins, USA. 12 p. 
De Bano, L.F., Neary, D.G., Elliott, P.F. 1998. Fire's Effects on

Ecosystems. John Wiley \& Sons, Inc., New York, USA. 333 p.

Doerr, S.H., Shakesby, R.A., Walsh, R.P.D. 1998. Spatial variability of soil hydrophobicity in fire-prone Eucalyptus and pine forests, Portugal. Soil Science 163: 313-324.

Doerr, S.H., Thomas, A.D. 2000. The role of soil moisture in controlling water repellency: New evidence from forest soils in Portugal. Journal of Hydrology 231- 232: 134-147.

Hallett, P.D. 2008. A Brief Overview of the Causes, Impacts and Amelioration of Soil Water Repellency - a Review. Soil \& Water Research 3: S21-S29.

King, P.M. 1981. Comparison of methods for measuring severity of water repellence of sandy soils and assessment of some factors that affect its measurement. Australian Journal of Soil Research 19: 275-285.

Krolow, I. R. C., Rheinheimer, D. dos S., Pellegrini, A., Alvarez, J. W. R., Krolow, D. R. V., Mohammed, B. 2019. Sediment Losses in Watersheds in the Western-Center Meso-Region Rio-grandense. Comunicata Scientiae 10: 98-108.

Meeuwig, R.O. 1970. Sheet erosion on intermountain summer ranges. United States

Department of Agriculture, Forest Service Intermountain Forest Range Experimental Station, Ogden, UT. 25 p.

Robichaud, P.R., Beyers, J.L., Neary, D.G. 2000. Evaluating the effectiveness of post fire rehabilitation treatments. General Technical Reports RMRS-GTR-63, Fort Collins, USA. $85 \mathrm{p}$.

Robichaud, P.R., Lewis, S.A., Ashmun, L.E. 2008. New procedure for sampling infiltration to assess post-fire soil water repellency. Research Note RMRS-RN-33, Fort Collins, USA. 14 p.

Shakesby, R.A., Doerr, S.H., Walsh, R.P.D. 2000. The erosional impact of soil hydrophobicity: Current problems and future research directions. Journal of Hydrology 231232: 178-191.

Tillman, W., Scotter, D.R., Wallis, M.G., Clothier, B.E. 1989. Water-repellency and its measurement by using intrinsic sorptivity. Australian Journal of Soil Research 27: 637-644.

Conflict of Interest Statement: The authors declare that the research was conducted in the absence of any commercial or financial relationships that could be construed as a potential conflict of interest.

All the contents of this journal, except where otherwise noted, is licensed under a Creative Commons Attribution License attribuition-type BY. 